\title{
An Overview of
}

Environmental Control

Aspects for the Gas-Cooled

Fast Reactor

\author{
A. M. Nolan
}

May 1981

Prepared for the U.S. Department of Energy under Contract DE-AC06-76RLO 1830

Pacific Northwest Laboratory

Operated for the U.S. Department of Energy

by Battelle Memorial Institute 
NOTICE

This report was prepared as an account of work sponsored by the United States Government. Neither the United States nor the Department of Energy, nor any of their employees, nor any of their contractors, subcontractors, or their employees, makes any warranty, express or implied, or assumes any legal liability or responsibility for the accuracy. completeness or usefulness of any information, apparatus, product or process disclosed, or represents that its use would not infringe privately owned rights.

The views, opinions and conclusions contained in this report are those of the contractor and do not necessarily represent those of the United States Government or the United States Department of Energy.

\author{
PACIFIC NORTHWEST LABORATORY \\ operated by \\ BATTELLE \\ for the \\ UNITED STATES DEPARTMENT OF ENERGY \\ Under Contract DE-AC06-76RLO 1830
}
Printed in the United States of America Available from
National Technical Information Service
United States Department of Commerce
5285 Port Royal Road
Springfield, Virginia 22151

Price: Printed Copy 5

$\therefore$ Microfiche $\$ 3.00$

\title{
NTIS
-Pages Selling Price
}

$\begin{array}{ll}001-025 & \$ 4.00 \\ 026-050 & \$ 4.50 \\ 051-075 & \$ 5.25 \\ 076-100 & \$ 6.00 \\ 101-125 & \$ 6.50 \\ 126-150 & \$ 7.25 \\ 151-175 & \$ 8.00 \\ 176-200 & \$ 9.00 \\ 201-225 & \$ 9.25 \\ 226-250 & \$ 9.50 \\ 251-275 & \$ 10.75 \\ 276-300 & \$ 11.00\end{array}$




\section{7}

AN OVERVIEW OF

ENVIRONMENTAL CONTROL

ASPECTS FOR THE GAS-COOLED

FAST REACTOR

A. M. Nolan

May 1981

Prepared for

the Environmental and Safety

Engineering Division,

U.S. Department of Energy

under Contract DE-ACO6-76RLO 1830

Pacific Northwest Laboratory

Richland, Washington 99352 


\section{SUMMARY}

Environmental control aspects relating to release of radionuclides have been analyzed for the Gas-Cooled Fast Reactor (GCFR). Information on environmental control systems was obtained for the most recent GCFR designs, and was used to evaluate the adequacy of these systems.

The GCFR has been designed by the General Atomic Company as an alternative to other fast breeder reactor designs, such as the Liquid Metal Fast Breeder Reactor (LMFBR). The GCFR design includes mixed oxide fuel and helium coolant.

The environmental impact of expected radionuclide releases from normal operation of the GCFR was evaluated using estimated collective dose equivalent commitments resulting from 1 year of plant operation. The results were compared to equivalent estimates for the Light Water Reactor (LWR) and HighTemperature Gas-Cooled Reactor (HTGR). A discussion of uncertainties in system performances, tritium production rates, and radiation quality factors for tritium is included.

This overview indicates that radioactive effluents from the GCFR would have less environmental impact in terms of collective dose equivalent commitment than those from other reactor types. Most of the difference is due to features inherent in the GCFR design, particularly the vented fuel concept. It thus appears that as it is currently envisioned, the GCFR environmental control technology for controlling radioactive effluents meets existing standards. No further overview studies on the GCFR concept are indicated. 


\section{CONTENTS}

SUMMARY

GLOSSARY

INTRODUCTION

CONCLUSIONS AND RECOMMENDATIONS

GAS-COOLED FAST REACTOR DESCRIPTION

ENVIRONMENTAL CONTROL SYSTEMS .

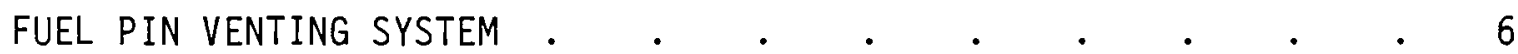

HELIUM PURIFICATION SYSTEM $\quad$ • $\quad$ •

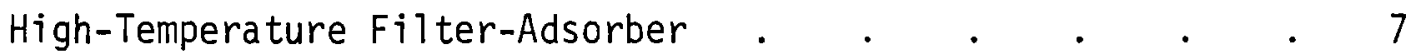

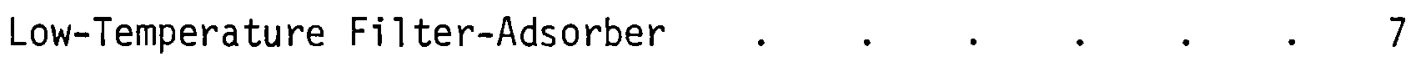

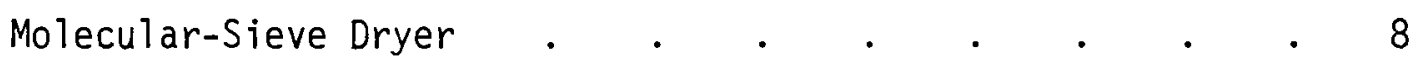

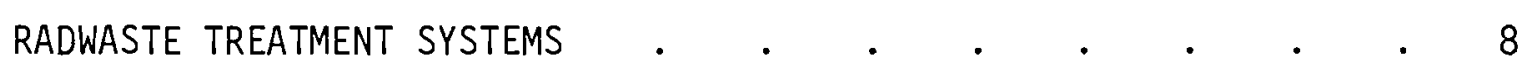

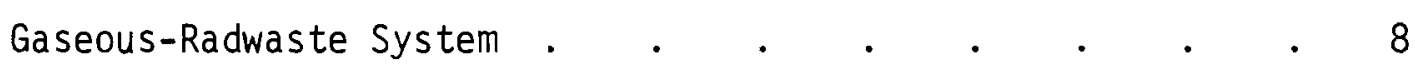

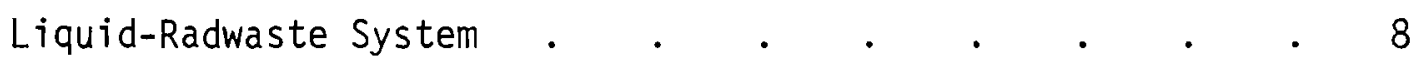

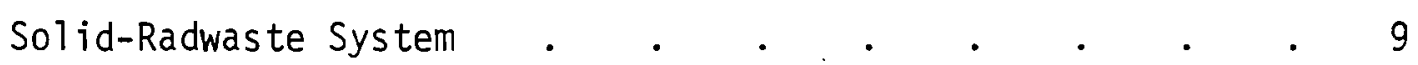

RADIONUCLIDE RELEASE PATHWAYS • • • • • • •

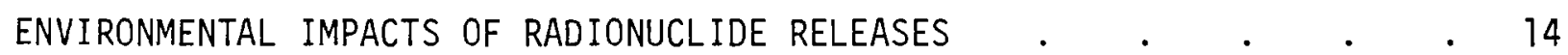

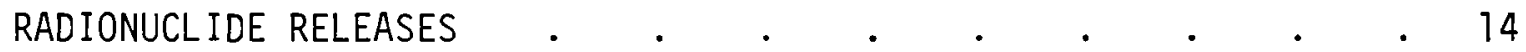

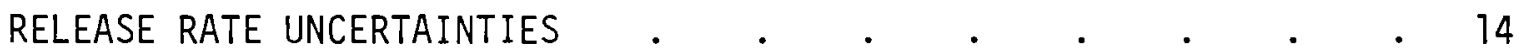

Environmental Control System Uncertainties . $\quad . \quad$. 14

Uncertainties in Fission Yields for Tritium . $. \quad . \quad$. 16

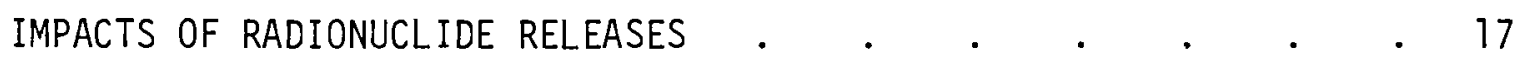

Collective Dose Equivalent Commitment Factors . . . 17

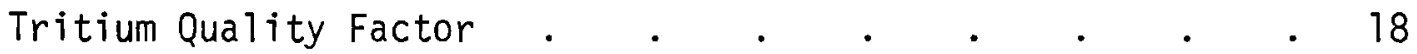


Collective Dose Equivalent Commitments $\quad$. $\quad . \quad$. $\quad$. $\quad$. 19

REFERENCES

\section{FIGURES}

1 Pathways During Helium Purification System Regeneration and Radioactive Gas Waste System Operation Leading to Radioactive Effluents.

2 Pathways During Normal Plant Operation Leading to Radioactive Effluents.

. . . . . .

\section{$\underline{\text { TABLES }}$}

1 Principal Design Characteristics of the GCFR . . . . .

2 Definitions and Values of Factors for Pathways from the HeliumPurification System to Radioactive Effluents. . . .

3 Definitions and Values of Factors for Pathways Leading to Radioactive Effluents from Normal Plant Operation.

4 Comparison of Liquid Releases to the Environment from the GCFR, HTGR, and LWR

5 Comparison of Gaseous-Effluent Releases to the Environment from the GCFR, HTGR, and LWR

6 Fifty-Year Collective Dose Equivalent Commitments (person-rem) for a 1-Year Release from the 1000-MWe GCFR, HTGR, and LWR

7 Fifty-Year Collective Dose Equivalent Commitments (person-rem) for a 1-Year Release of Tritium from the 1000-MWe GCFR . 


\section{$\underline{\text { GLOSSARY }}$}

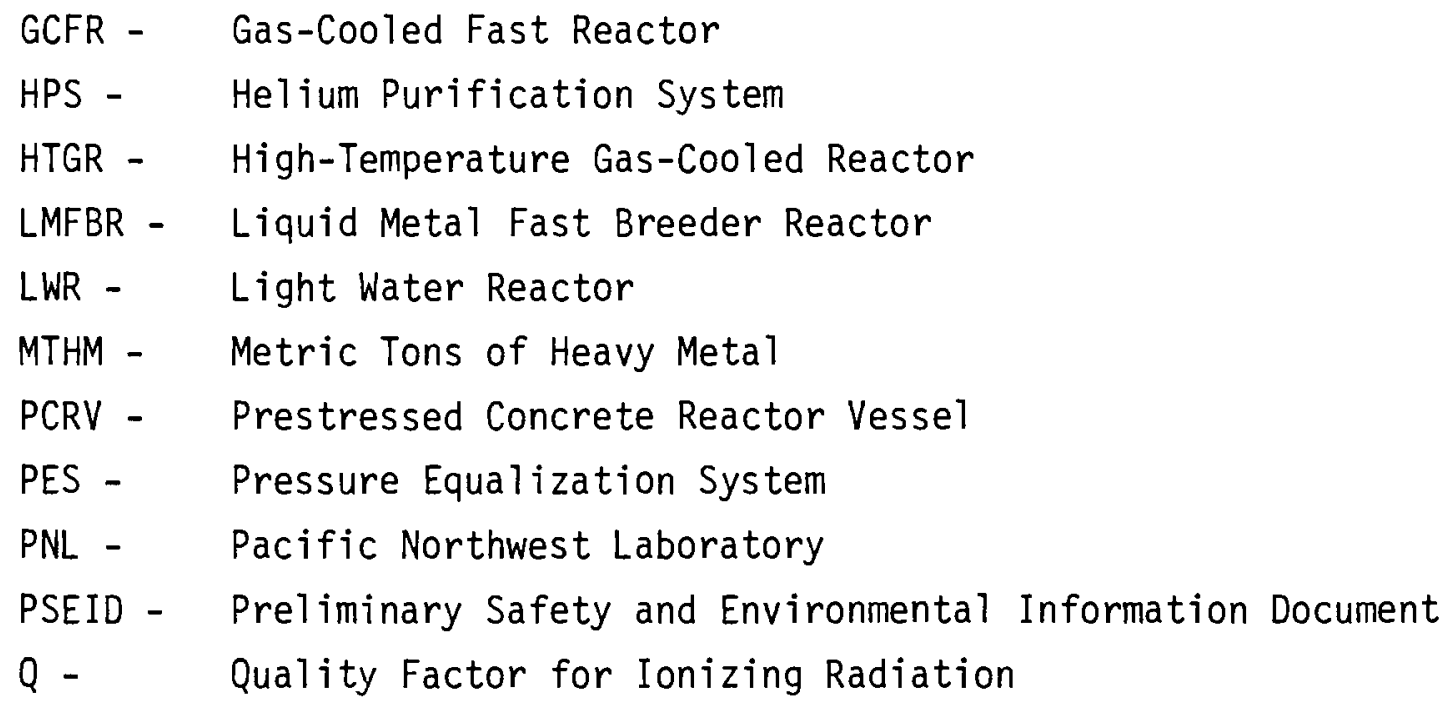


The Department of Energy's Division of Environmental and Safety Engineering has an ongoing program at the Pacific Northwest Laboratory (PNL) to evaluate the environmental control aspects of developing nuclear technologies. As part of this program, PNL has conducted an overview of the environmental control technology aspects of the current GCFR design. The objective of this study is to review the expected environmental impacts for the GCFR to assess the adequacy of the technology being designed and developed for the control of radioactive effluents.

This summary of the overview includes a brief description of the GCFR and discussions of the environmental control systems and expected environmental impacts resulting from normal operation of the GCFR. Environmental impacts of accidents and fuel cycle activities are beyond the scope of this study. 


\section{CONCLUSIONS AND RECOMMENDATIONS}

The expected environmental effects of normal operation of the GCFR were compared with those of operating an LWR and HTGR. Collective dose equivalent commitments to the surrounding human population from releases of radionuclides were estimated for each reactor type and used as the basis of comparison.

The results indicate that operation of a GCFR would result in lower collective dose equivalent commitments than operation of either the LWR or HTGR. Inherent design features, as well as the effluent control technology being developed for the GCFR, are thus expected to adequately limit radionuclide releases from an operating reactor of this type. No need was identified for development of environmental control systems to further limit normal operational radionuclide releases. 


\section{GAS-COOLED FAST REACTOR DESCRIPTION}

The Gas-Cooled Fast Reactor (GCFR) was developed by taking maximum advantage of the helium-coolant technology and components developed for the High-Temperature Gas-Cooled Reactor (HTGR) and the fuel-element developmental work on the Liquid Metal Fast Breeder Reactor (LMFBR) programs.

The principal components of the nuclear steam supply system are contained in a pre-stressed concrete reactor vessel (PCRV). The PCRV is a concrete structure reinforced with steel rods and pre-stressed by a system of longitudinal and circumferential steel tendons. Inside the PCRV are a number of steel-lined interconnected cavities; three contain the main helium circulators and steam generators and three contain the core auxiliary cooling equipment. These are arranged around the central cavity which contains the reactor. During operation the primary coolant, helium, passes through the reactor core, where it is heated by the fission process of $\mathrm{PuO}_{2}$ and $\mathrm{UO}_{2}$ to a temperature of $1067^{\circ} \mathrm{F}$ at a pressure of about $1250 \mathrm{psi}$. The helium transfers its heat to the steam generators and returns to the core.

The secondary coolant system conveys steam produced in the steam generators to the turbine generator for conversion of the thermal energy into electrical energy.

The reactor is rated at 3290 MWt and comprises 253 hexagonal core and radial blanket elements supported from a top-mounted single grid plate to which each element is rigidly attached at its upper end. The standard fuel element consists of 324 fuel rods that are similar to those used in LMFBR designs. The fuel rods contain sintered $\mathrm{PuO}_{2}-\mathrm{UO}_{2}$ pellets in a Type 316 stainless steel cladding that is $17 \mathrm{mils}$ thick. The cladding is roughened to improve the surface heat transfer. Each element is equipped with an orifice that permits adjustment of the coolant flow to achieve an approximately uniform hot-spot cladding temperature in each element.

Pressure in the fuel rods is equalized to that of the reactor coolant by collective venting. The fission gases diffusing from the fuel rods pass through the vent manifold to the helium purification system. Pressure equalization 
relieves the cladding from mechanical stresses due to external gas coolant pressure and internal fission-product gas pressure. This system also limits the release of activity from failed rods to the reactor coolant.

The helium purification system is required, over the life of the plant, to remove and store impurities from the reactor coolant system until they can be safely released to the environs or transferred to the waste disposal systems. The helium purification system will be contained within the PCRV and will operate at the reactor coolant pressure.

Radioactive gases or potentially radioactive gas streams are collected in the radioactive-gas-waste system. The waste-gas compressors compress these gases into the waste-gas surge tanks. Subsequently, this gas is processed through the gas recovery system. The gas recovery system achieves separation of radioactive and chemical impurities on the basis of chromatographic adsorption. Moisture, $\mathrm{CO}_{2}, \mathrm{CO}, \mathrm{N}_{2}$, and $\mathrm{O}_{2}$ are released to the atmosphere after separation. The other gases are returned to the reactor or disposed of as waste. The most important design and operating parameters for the GCFR are summarized in Table 1. 
TABLE 1. Principal Design Characteristics of the GCFR

$\begin{array}{lc}\text { Reactor thermal power output, MW } & 3,290 \\ \text { Net electrical power output, MW } & 1,200 \\ \text { Plant heat rate, Btu/kW-hr } & 9,360 \\ \text { Core heat output, MW } & 3,165+125 \text { from the blankets } \\ \text { Core volume, liters } & 14,605 \\ \text { Core loading, } \mathrm{kg} & \\ \text { Heavy metal } & 33,560 \\ \text { Fissile fuel } & 4,439 \\ \text { Conversion ratio } & 1.51 \\ \text { Average discharge burnup, MWd/MTHM (a) } & 81,000 \\ \text { Peak discharge burnup, MWd/MTHM }(\mathrm{a}) & 92,000 \\ \text { Fuel type } & 0 \times 1 \mathrm{de} \\ \text { Reactor inlet temperature, }{ }^{\circ} \mathrm{F} & 600 \\ \text { Reactor outlet temperature, }{ }^{\circ} \mathrm{F} & 1,067 \\ \text { End-of-cycle excess reactivity } & 0 \\ \text { Geometric information } & \\ \text { Core height, cm } & 127 \\ \text { Number of core enrichment zones } & 4 \\ \text { Number of assemblies } & 253 \\ \text { Number of pins per assembly } & 324 \\ \text { Overall assembly length, cm } & 447 \\ \text { Lattice pitch, cm } & 1.14 \\ \text { Assembly material } & \text { Type } 316 \text { stainless steel } \\ \text { Cladding parameters } & \\ \text { Cladding outside diameter, mils } & 315 \\ \text { Cladding wall thickness, mils } & 17 \\ \text { Cladding material } & \text { Type of } 316 \text { stainless steel } \\ & \end{array}$

(a) Metric tons of heavy metal charged to the reactor. 


\section{ENVIRONMENTAL CONTROL SYSTEMS}

The environmental impacts of an operating reactor include thermal impacts, water and land use, and chemical and radioactive releases. This overview of the GCFR environmental control systems is concerned only with those systems that limit the normal operational releases of radioactivity to the environment.

In the GCFR system, radioactivity is produced by the fission process and by the neutron activation of coolant impurities. The helium coolant does not significantly activate. Releases of the radioactivity are controlled by a variety of systems.

\section{FUEL PIN VENTING SYSTEM}

Radioactive fission products are retained within the fuel pins in the standard LWR or LMFBR systems. In the GCFR, however, the fuel pins are vented. Fission gases produced during fuel burnup are collected in a plenum at the top of each fuel rod. The pressure equalization system (PES) sweeps the fission gases out of the plenum to a helium purification system (HPS), which removes the fission products as well as impurities. By this means, the pressure inside the fuel pins is maintained at a point just below the coolant pressure.

Fission gases and volatiles produced during fuel burnup diffuse out of the mixed oxide ceramic and collect in a plenum at the top of each fuel rod. Before reaching the plenum, however, the blanket region between the active fuel and the plenum must be traversed. This blanket region causes some holdup and delay and also provides a site for plateout of significant porticns of the volatile species.

When the gases and volatiles reach the plenum, a stream of helium sweeps them on through an annular charcoal trap and to the HPS. The charcoal trap provides some delay for the noble gases and also captures the volatiles species.

Tests on the vented fuel pin concept have been performed over recent years. The results of these tests have been reported (Langer, Buzzelli, and Flynn 1975; Goodin, Langer, and Be11 1980; Acharya, Campana, and Langer 1980), and indicate that the performance of the venting system and charcoal trap is as good as or better than expected. Such radionuclide species as iodine are essentially 
completely retained by the charcoal trap. Gases are the only species vented to the HPS. The tests were conducted for realistic fuel burnups ( $1100,000 \mathrm{MWd} / \mathrm{MTHM}$ ) and linear power levels $(48 \mathrm{~kW} / \mathrm{ft}$ ), and included a simulation of a leaking fuel element.

The vented fuel pin design makes the GCFR unique among reactor designs. The technology for removing fission products and impurities from helium coolant was developed for the HTGR and has been applied to the GCFR for both coolant cleanup and the venting system. The fuel pin venting system reduces the coolant radionuclide inventory which in turn reduces releases through primary and secondary containment leaks. The lower pressure in the fuel pins also aids in reducing fuel clad failures. In the event of a failure, coolant will be pulled into the fuel pin, sweeping fission products on to the HPS rather than releasing them to the primary coolant.

\section{HELIUM PURIFICATION SYSTEM}

The HPS removes coolant impurities as well as fission gases vented from the fuel. The system consists of a high-temperature adsorber, a low-temperature adsorber, and an oxidizer combined with a molecular-sieve dryer for tritiated water removal. These components trap most of the volatiles, noble gases, and tritium, and are either regenerated or replaced as necessary. The HPS for the GCFR is basically the same system as that used for the HTGR. The main components of the HPS are described briefly below.

\section{High-Temperature Filter-Adsorber}

This component consists of a charcoal bed which traps virtually all of the volatile fission products that enter it. The bed is replaced approximately once a month, and is treated as solid radwaste.

\section{Low-Temperature Filter-Adsorber}

The noble gases, mostly krypton and xenon, are separated cryogenically from other gaseous wastes. The adsorber is periodically regenerated and the gases are further processed in the gaseous radwaste system. 


\section{Molecular-Sieve Dryer}

Tritium is released from the fuel pins by diffusion through the stainless steel clad to the reactor coolant. The tritium occurs in two forms: tritiated water (HTO) and unoxidized gas (HT). The HPS includes an oxidizer which converts essentially all of the HT to HTO. The molecular-sieve dryer than traps all water, including HTO, by an adsorbtion process.

Earlier designs for the HPS omitted the oxidizer and used a titanium sponge to adsorb $\mathrm{H}_{2}$ and HT. Rising costs of titanium, however, prompted the change to the current concept. One benefit of oxidizing the $\mathrm{H}_{2}$ and $\mathrm{HT}$ is a longer life for the low temperature adsorber. This in turn allows the low temperature adsorber to be off-line for a longer period of time before regeneration, permitting more decay of radioactive materials before they enter the radwaste systems.

\section{RADWASTE TREATMENT SYSTEMS}

The radwaste systems treat the wastes that results from the regeneration or replacement of HPS components and from general plant wastes. A brief description of each of the radwaste systems follows.

\section{Gaseous-Radwaste System}

The gaseous-radwaste system is designed to collect potentially radioactive gases generated during plant operation. These gases will either be vented to the environment, retained within the helium-purification system, held for radioactive decay before disposal, or bottled for onsite stcrage. The choice depends on the level of activity present.

Gaseous effluents released from the fuel include helium, hydrogen, tritium, oxygen, carbon dioxide, carbon monoxide, krypton, xenon, and iodine. Only helium is returned to the reactor coolant. Tritium is removed from the coolant by oxidation into the chemical form of water, followed by suitable disposal.

\section{Liquid-Radwaste System}

The liquid-radwaste system is designed to collect potentially radioactive liquids generated during plant operation and then either store, process, or 
dispose of them. Most of the liquid wastes generated in a plant result from decontamination operations, showers, laundry, process sampling, or maintenance liquid releases. Only limited quantities of other waste liquids are produced.

Liquid wastes with low levels of total dissolved solids are normally filtered, demineralized, and collected in waste-monitoring tanks. Those with high levels of total dissolved solids are normally filtered, treated by reverse osmosis and ion exchange, and collected in waste monitoring tanks, where they are sampled before being recycled or discharged. Waste concentrates are ultimately processed in the solid-radwaste system.

Solid-Radwaste System

The solid-radwaste system is designed to process, package and store for ultimate disposal the solid radioactive waste generated during plant operation and maintenance. The wastes include tritiated concrete, reverse-osmosis concentrates, used filters, demineralizer resins, and other contaminated solid refuse. The total volume of low-level solid waste is expected to be approximately 1,400 $\mathrm{ft}^{3}$ annually with an activity content of 280 curies (DOE 1980).

\section{RADIONUCLIDE RELEASE PATHWAYS}

Figure 1 shows schematically the relationships among the systems described above. System performance data shown in Table 2 can be used to trace the pathways of the various nuclides through the systems.

Other pathways for radioactive releases involve transport of radionuclides to the secondary coolant and to the secondary containment. There are always small leaks to be considered, and these leaks will allow releases of small quantities of radionuclides.

Figure 2 shows these pathways for normal plant operation, with Table 3 defining the pathway factors shown.

The most important system for control of radionuclide releases is the helium purification system. This is the point at which almost all of the radionuclides are removed from the reactor coolant, separated, and sent to the radwaste systems 


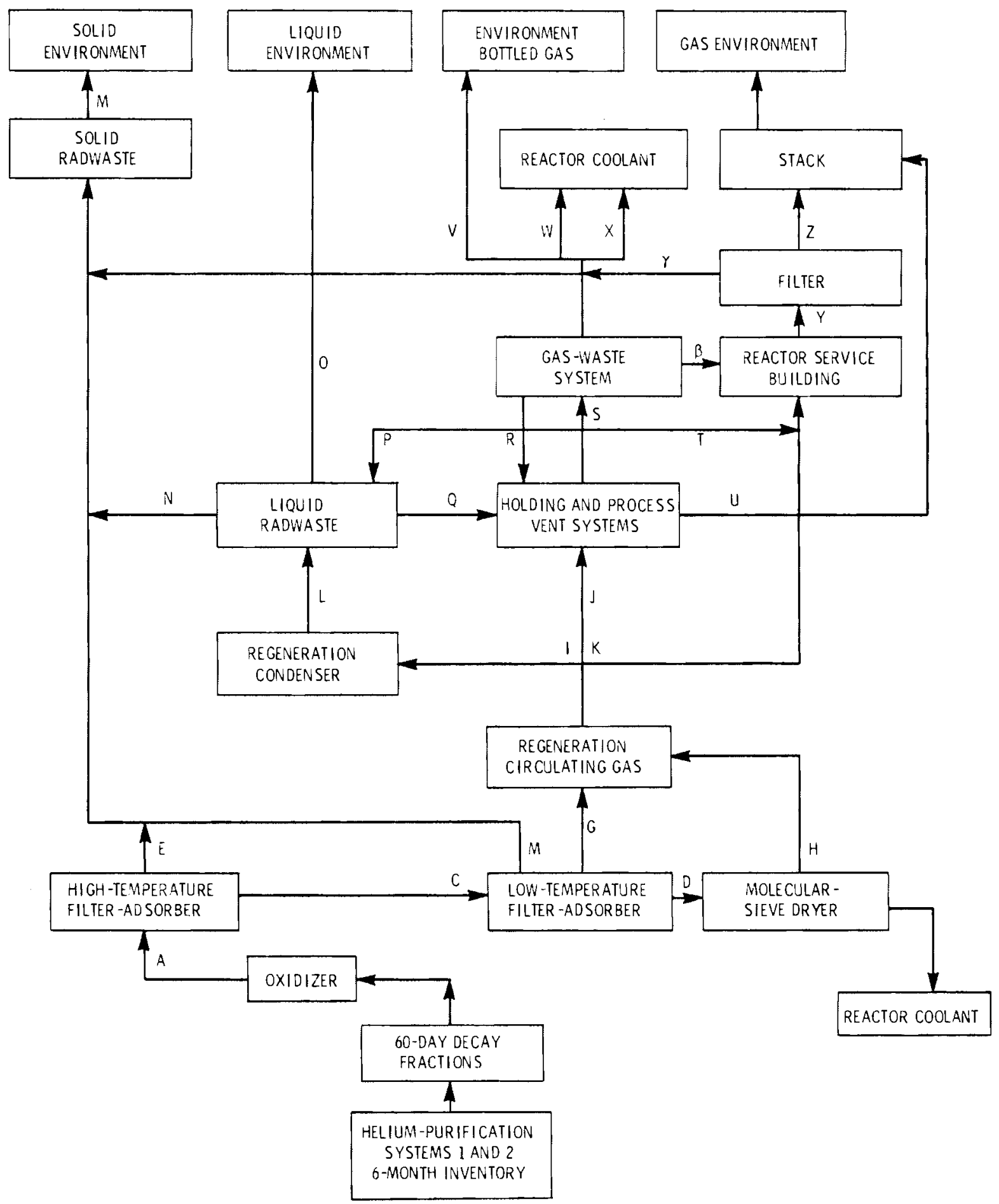

NOTE: DEFINITIONS AND QUANTITATIVE VALUES OF THE FACTORS SHOWN ALONG PATHWAYS ARE GIVEN IN TABLE $?$

FIGURE 1. Pathways During Helium Purification System Regeneration and Radioactive Gas Waste System Operation Leading to Radioactive Effluents 
TABLE 2. Definitions and Values of Factors for Pathways from the Helium-Purification System to Radioactive Effluents (a)

\begin{tabular}{|c|c|c|}
\hline Factor & Definition & Value \\
\hline A & Fraction of condensables trapped on charcoal bed & 1.00 \\
\hline C & $\begin{array}{l}\text { Fractions of krypton, xenon, and decay products on } \\
\text { liquid-nitrogen charcoal bed }\end{array}$ & 1.00 \\
\hline D & Fraction of tritium trapped as HTO on molecular sieve & 1.00 \\
\hline $\mathrm{E}$ & Bed-replacement frequency per year & 0.1 \\
\hline G & Desorption fraction & 1.00 \\
\hline H & Regeneration fraction & 1.00 \\
\hline I & Condensed fraction $\left(\mathrm{H}_{2} \mathrm{O}+\mathrm{HTO}\right)$ & 0.99 \\
\hline J & Purge fraction & 1.00 \\
\hline K & Regeneration HPS leakage fraction per year & $5.68 \times 10^{-8}$ \\
\hline L & Drainage fraction $\left(\mathrm{H}_{2}+\mathrm{HTO}\right)$ per year & $1.0 \times 10^{-6}$ \\
\hline M & Removal frequency during plant life & 1 \\
\hline N & Tritiated-concrete-casting removal frequency per year & 2 \\
\hline 0 & Tritiated-vapor leakage fraction & $1 \times 10^{-6}$ \\
\hline P & Gaseous-radwaste drainage fraction & $1 \times 10^{-6}$ \\
\hline Q & Liquid-radwaste venting fraction & 0.01 \\
\hline$R$ & Gas-waste-system flushing return fraction & 0.01 \\
\hline$S$ & Gas-waste-system processing fraction & 1.00 \\
\hline $\mathrm{T}$ & Holding-system leakage fraction per year & $6.25 \times 10^{-7}$ \\
\hline U & Process-vent-system leakage fraction & 0.00 \\
\hline V & Krypton and xenon bottling fraction & 0.80 \\
\hline W & Hydrogen and tritium coolant return fraction & 0.02 \\
\hline$x$ & Krypton and xenon fraction returned to reactor coolant & 0.00 \\
\hline Y & Reactor-service-building vent dilution factor, $\mathrm{cfm}$ & 190,660 \\
\hline Z & Filter decontamination factor & 1.00 \\
\hline$\beta$ & Gas-recovery-system leakage fraction per year & $1.87 \times 10^{-7}$ \\
\hline$\gamma$ & Filter-replacement frequency per year & 1 \\
\hline
\end{tabular}

(a) See Figure 1. 


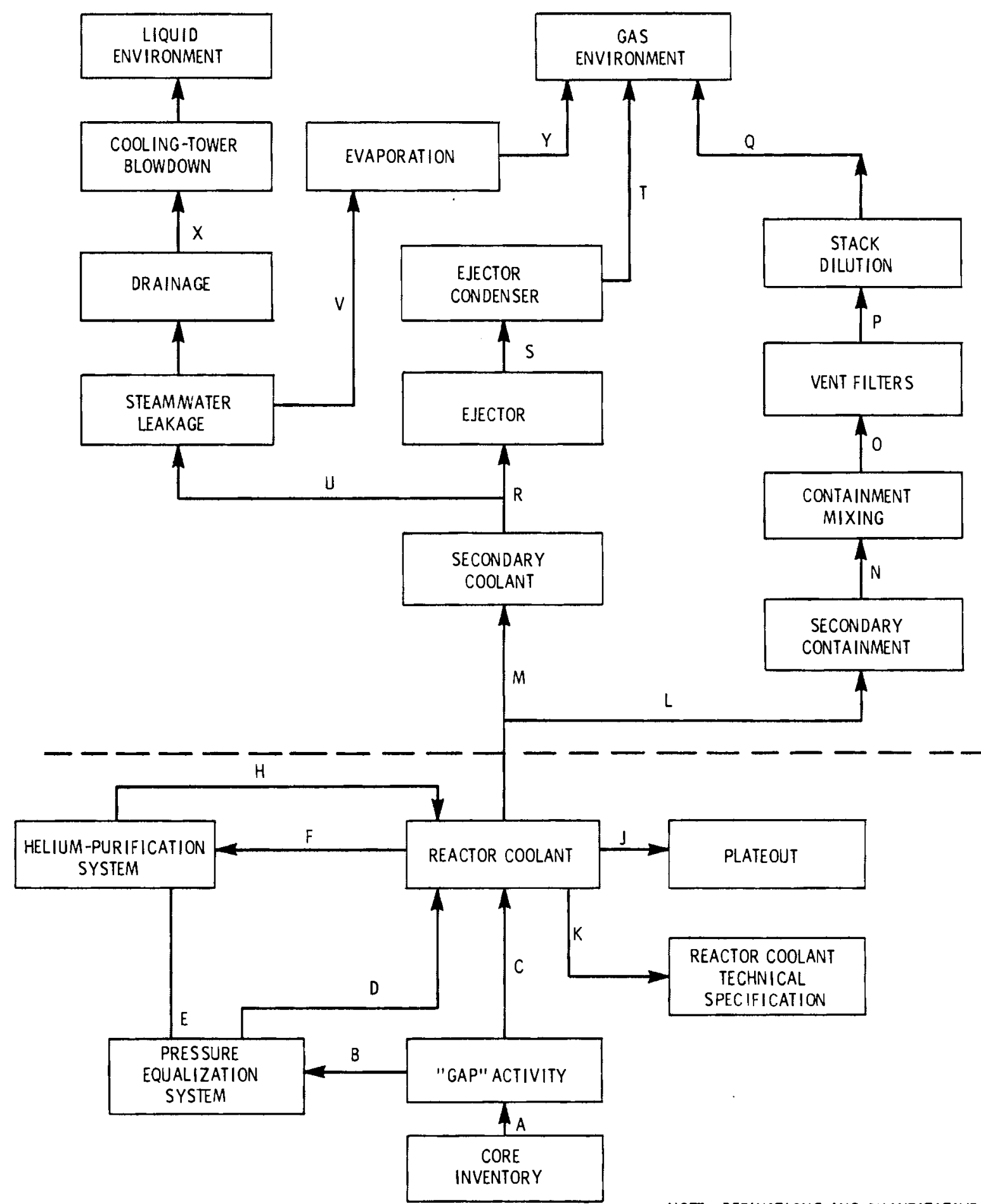

NOTE: DEFINITIONS AND QUANTITATIVE VALUES OF THE FACTORS SHOWN ALONG PATHWAYS ARE GIVEN IN TABLE 3

FIGURE 2. Pathways During Normal Plant Operation Leading to Radioactive Effluents 
TABLE 3. Definitions and Values of Factors for Pathways Leading to Radioactive Effluents from Normal Plant Operation(a)

\begin{tabular}{|c|c|c|}
\hline Factor & Definition & Value \\
\hline A & Release-to-birth-rate ratio ( $R / B)$ & See DOE 1980 \\
\hline B & Venting-to-release-rate ratio (venting fraction) & See DOE 1980 \\
\hline$C, D$ & Defects, suction hole, and vent connection escape rate & $3 \times 10^{-6}$ \\
\hline E & Collection and storage fraction & 1.0 \\
\hline $\mathrm{F}$ & $H_{P S}(b), ~ p r o c e s s$ rate fraction, $1 \mathrm{~b} / \mathrm{hr}$ & $\begin{array}{l}5,330(15.6 \% \text { per } \\
\text { hr })\end{array}$ \\
\hline H & HPS 1 removal fraction & 1.0 (0.99 for tritium) \\
\hline $\mathrm{J}$ & Plateout removal fraction per cycle, $\%$ & $\begin{array}{l}20 \text { for iodine, } 0.2 \\
\text { for volatiles }\end{array}$ \\
\hline k & Design and operating margin & To be established \\
\hline L & PCRV leak rate, $10^{-2} \mathrm{lb} / \mathrm{hr}$ & $3.9(1 \%$ per year $)$ \\
\hline M & Tritium permeation fraction & $9 \times 10^{-6}$ \\
\hline N & Secondary containment volume, $10^{6} \mathrm{ft}^{3}$ & 4.03 \\
\hline 0 & Mixing factor & 1.0 \\
\hline$P$ & Filter decontamination factor and venting rate & $1.0(28,330 \mathrm{cfm})$ \\
\hline Q & Stack dilution factor & 6.73 \\
\hline $\mathrm{R}$ & Ejector steam fraction of secondary coolant, \% per hour & 0.0258 \\
\hline$S$ & Ejector condenser return fraction, $\%$ & 84 \\
\hline$T$ & Ejector condenser vented fraction, $\%$ & 16 \\
\hline U & Secondary-coolant leakage fraction & $4.54 \times 10^{-3}$ \\
\hline V & Secondary-coolant leakage evaporated fraction, $\%$ & 30 \\
\hline W & Secondary-coolant leakage drainage fraction, $\stackrel{\%}{\%}$ & 70 \\
\hline$x$ & Cooling-tower-blowdown dilution factor & 20 \\
\hline Y & Turbine-building ventilation rate, cfm & 94,660 \\
\hline
\end{tabular}

(a) See Figure 2 .

(b) Helium-purification system.

for further processing. This system keeps the reactor coolant radionuclide inventory low. This minimizes releases resulting from PCRV leakage and primary to secondary leakages, pathways which can account for a great deal of a nuclear plant's releases to the environment. 


\section{ENVIRONMENTAL IMPACTS OF RADIONUCLIDE RELEASES}

Normal operation of a GCFR will involve release of small quantities of radionuclides to the environment. Radionuclides are dispersed to the environment through gaseous and liquid pathways. The environmental effect of greatest concern is the exposure to human populations as a result of plant operations.

\section{RADIONUCLIDES RELEASES}

The annual radionuclide releases expected to result from normal operation of a GCFR have been estimated in the Preliminary Safety and Environmental Information Document (PSEID) for the GCFR (DOE 1980). Estimates of core radionuclide inventory have been combined with system performance data and expected leakage or diffusion rates to produce the release estimate.

Annual liquid and gaseous releases expected from an operating GCFR are listed by radionuclide in Tables 4 and 5 . Included for comparison are routine releases for a standard LWR and HTGR.

\section{RELEASE RATE UNCERTAINTIES}

As with any facility that has been designed but not operated, some uncertainty exists as to what the actual facility performance will be. There are two principal areas of uncertainty for releases from GCFR: environmental control systems and tritium yields from fast fissions.

Environmental Control System Uncertainties

Many of the radwaste systems projected for use at a GCFR plant have already been demonstrated at LWRs or HTGRs. In addition, all other systems relating to radionuclide releases, including those involved with the fuel venting concept, have been tested to determine the actual performance to be expected. Thus, the system performances discussed in the previous chapter are probably fairly accurate estimates of what would be expected from an operating, full-scale GCFR. Environmental control systems are designed with a considerable degree of 
TABLE 4. Comparison of Liquid Releases to the Environment from the GCFR, HTGR, and LWR

\begin{tabular}{lccc} 
& \multicolumn{3}{c}{ Release (Ci/yr) } \\
\cline { 5 - 5 } \multicolumn{1}{c}{ Isotope } & GCFR & HTGR & LWR \\
\cline { 5 - 5 } Bromine-83 & 0.0021 & -- & 0.0001 \\
Bromine-84 & 0.0018 & $4.00-5$ & -- \\
Bromine-85 & 0.0014 & 0.0002 & -- \\
Rubidium-88 & 0.0012 & 0.0003 & -- \\
Strontium-89 & $6.00-6$ & 0.0001 & 0.0002 \\
Strontium-91 & 0.0001 & -- & $6.00-5$ \\
Strontium-90 & $1.63-8$ & 0.0008 & -- \\
Strontium-94 & $3.60-6$ & $2.00-5$ & -- \\
Yttrium-90 & $1.63-8$ & 0.0064 & -- \\
Yttrium-91 & $3.13-8$ & -- & 0.0001 \\
Yttrium-91m & $7.83-5$ & -- & $2.00-5$ \\
Tellurium-127m & $2.97-6$ & $1.40-4$ & 0.0001 \\
Tellurium-127 & 0.0010 & $1.40-4$ & 0.0002 \\
Tellurium-129m & 0.0001 & $1.70-4$ & 0.0003 \\
Tellurium-129 & 0.0114 & $1.70-4$ & 0.0005 \\
Tellurium-131 & $1.46-2$ & $2.50-5$ & 0.0001 \\
Tellurium-132 & 0.0041 & -- & 0.01 \\
Tellurium-133m & 0.0141 & $3.50-5$ & -- \\
Tellurium-133 & 0.0003 & $2.60-5$ & -- \\
Tellurium-134 & 0.0164 & $4.30-5$ & -- \\
Iodine-131 & $8.27-6$ & -- & 0.14 \\
Iodine-132 & $4.10-5$ & -- & 0.01 \\
Iodine-133 & $4.93-5$ & -- & 0.1 \\
Iodine-134 & 0.0002 & $4.30-5$ & $7.00-5$ \\
Iodine-135 & $6.43-5$ & -- & -- \\
Iodine-136 & $6.90-5$ & $1.30-4$ & -- \\
Cesium-134 & $6.67-6$ & 0.015 & 0.01 \\
Cesium-136 & $1.43-4$ & --- & 0.005 \\
Cesium-138 & 0.0286 & $3.50-5$ & -- \\
Cesium-139 & 0.0065 & $2.60-5$ & -- \\
Cesium-140 & 0.0003 & $8.60-5$ & -- \\
Barium-137m & $1.73-6$ & 0.029 & 0.01 \\
Barium-139 & 0.0087 & -- & $4.00-5$ \\
Barium-140 & $3.70-5$ & -- & 0.0002 \\
Lanthanum-140 & $3.70-5$ & -- & 0.0001 \\
Cerium-143 & $5.40-6$ & -- & $1.00-5$ \\
Praseodymium-143 & $8.16-19$ & -- & $2.00-5$
\end{tabular}

NOTE: $4.00-5=4.00 \times 10^{-5}$.

Data reproduced from PSEID for GCFR

(DOE 1980). All plants normalized to 1000 Mhie. 
TABLE 5. Comparison of Gaseous-Effluent Releases to the Environment from the GCFR, HTGR, and LWR

\begin{tabular}{|c|c|c|c|}
\hline \multirow[b]{2}{*}{ Isotope } & \multicolumn{3}{|c|}{ Release (Ci/yr) } \\
\hline & GCFR & HTGR & LWR \\
\hline Krypton-83m & $7.93-3$ & 3.5 & 1.0 \\
\hline Krypton-85m & 0.0062 & 6.0 & 11.0 \\
\hline Krypton-85 & $1.33-6$ & $3,607.0$ & 380.0 \\
\hline Krypton-87 & 0.0055 & 8.0 & 2.0 \\
\hline Krypton-90 & $3.93-5$ & 1.5 & -- \\
\hline Xenon-131m & $6.63-5$ & -- & 44.0 \\
\hline Xenon-133m & 0.0012 & -- & 80.0 \\
\hline Xenon-133 & 0.0234 & 8.0 & $7,200.0$ \\
\hline Xenon-135m & 0.0049 & 3.5 & 1.0 \\
\hline Xenon-135 & 0.0513 & 6.0 & 50.0 \\
\hline Iodine-131 & $8.27-6$ & -- & 0.5 \\
\hline Iodine-132 & $4.10-5$ & -- & 0.06 \\
\hline Iodine-134 & 0.0002 & 0.0001 & -- \\
\hline Iodine- 135 & $6.43-5$ & 0.0002 & -- \\
\hline Tritium & 0.15 & 78.0 & 580.0 \\
\hline
\end{tabular}

conservatism to allow for performance uncertainties and to minimize releases. Actual system performances are often better than those assumed for estimating radionuclide or other releases.

Uncertainties in Fission Yields for Tritium

Fission yields in thermal reactors are fairly well known as a result of many years of experience. Recent work, however, has indicated that the tritium source term may have been underestimated for fast reactors.

Tritium is produced in several ways in a reactor, the primary sources in the GCFR being neutron activation of boron and the fission process itself. Tritium 
is a product of the ternary fission process, in which three fission products $\left({ }^{3} \mathrm{H}\right.$ and two heavier nuclides) result from a heavy element fission. The probability of this occurring has been about one in every $10^{4}$ fissions for uranium fissions in thermal reactors (LWRs and HTGR, for instance). The tritium yield from plutonium is somewhat higher, approaching 2 per $10^{4}$ fissions.

Lacking evidence to indicate otherwise, the same yields have been assumed for fast fissions. Work is now being conducted at ORNL to better determine fast fission yields for tritium. Preliminary results indicate that the yields for some nuclides may be an order of magnitude higher than previously thought. A discussion of the current status of this work is found in a recent survey of key environmental questions pertaining to tritium (Till, et al. 1980).

Using the assumption that tritium yields in fast reactors are the same as for thermal reactors, it is estimated that about $25 \%$ of the tritium produced in the GCFR is from boron activation. Most of the remainder comes from ternary fissions. If the tritium yield is doubled, the total amount of tritium produced would increase more than $60 \%$.

\section{IMPACTS OF RADIONUCLIDE RELEASES}

One method for estimating the impact of radionuclide releases is the calculation of collective dose equivalent commitments which would result from such releases. Collective dose equivalent commitment factors are used to relate the quantities of radionuclides released in a year of plant operation to the collective dose accumulated over the following 50 years.

\section{Collective Dose Equivalent Commitment Factors}

The factors that were used to calculate the relative collective dose equivalent commitments reported in this study are 50-year collective dose equivalent commitment factors for atmospheric and liquid releases at a generic midwestern site. The factors are in units of person-rem per curie of nuclide released, and have been estimated for four organs and the total body.

The generic midwestern site is characterized as follows:

- There is fenced boundary, including $4.7 \mathrm{~km}^{2}$ in a rectangular form $2.35 \mathrm{~km}$ by $2.0 \mathrm{~km}$. A moderately large river runs through one corner of the site. 
- The average population density out to an $80-\mathrm{km}$ radius is 174 persons/ $\mathrm{km}^{2}$, making a total population of $3.5 \times 10^{6}$ persons.

- The nearest dwelling is a farm house located $1.3 \mathrm{~km}$ from the site. A milk cow eats from the pasture for 7 months of the year and the garden is irrigated by water from the river.

- Drinking water and boating and swimming are the main uses of the river. Fish taken from the river are consumed at an average rate of $6.9 \mathrm{~kg} / \mathrm{yr}$.

- The site receives $61 \mathrm{~cm}(24 \mathrm{in.})$ of precipitation every year.

- The average annual wind speed is $14.8 \mathrm{~km} / \mathrm{hr}(9.2 \mathrm{mph})$. Air releases are from a $10-m$ stack.

- The river average annual flow rate is $1420 \mathrm{~m}^{3} / \mathrm{sec}(50,000 \mathrm{cfs})$.

The models used to calculate the collective dose equivalent commitment factors were developed by J. K. Soldat, E. C. Watson, D. A. Baker, D. L. Strenge and G. R. Hoenes. These models have been summarized by Brenchley, et al. (1977). Tritium Quality Factor

One quantity which determines the value of a collective dose equivalent commitment factor for a particular nuclide is the quality factor, or Q. The $Q$ is the linear-energy-transfer dependent factor by which absorbed doses are to be multiplied to obtain, for purposes of radiation protection, a quantity that expresses, on a common scale for all ionizing radiations, the irradiation incurred by exposed persons.

Recently, controversy has arisen over the proper Q for tritium. The International Commission on Radiological Protection (ICRP) recommended in 1969 that the value of 1.0 be used for the tritium $Q$, primarily because insufficient evidence existed to support a higher value. Since that time, experiments to measure the biological effectiveness of tritium radiation have been done, and the results indicate that a value of 1.7 is more likely the true Q (Till, Etnier, and Meyer 1980). The actual recommendation is to use a value of 2 , since a precision of one significant figure is all that can be justified. 
Doubling the $Q$ for tritium will double the predicted collective dose equivalent commitment for tritium releases. Since, as will be shown below, tritium is one of the major contributors to collective dose equivalent commitments for releases from all reactors, this increase in the tritium Q will increase the total estimated collective dose equivalent commitment.

\section{Collective Dose Equivalent Commitments}

Using the factors discussed above, and the expected nuclide releases provided in the PSEID for the GCFR, the resulting collective dose equivalent commitments have been estimated. The PSEID also provided estimated releases for a reference LWR and HTGR. Collective dose equivalent commitments for these releases have been estimated as well, and are included here for comparison purposes.

Table 6 shows collective dose equivalent commitments for a 1-year release from a GCFR, an LWR, and an HTGR. Commitments for both gaseous and liquid releases are included. As the data show, collective dose equivalent commitments from the GCFR releases are all lower than those from the other reactor types, in some cases by several orders of magnitude.

These results assume the standard tritium yields from fissions as well as a tritium $Q$ of 1 . Table 7 shows the collective dose equivalent commitments due to tritium alone, so that the effect of increased fission yields or $Q$ can be readily determined.

The principal nuclides involved in gaseous releases are tritium, ${ }^{87} \mathrm{Kr}$, ${ }^{88} \mathrm{Kr},{ }^{133} \mathrm{Xe}$ and ${ }^{135} \mathrm{Xe}$. For the thyroid, ${ }^{131} \mathrm{I}$ and ${ }^{133} \mathrm{I}$ also contribute significantly. Noble gases and tritium are expected to be released in far smaller quantities from the GCFR then from LWRS or HTGRs, thus accounting for the lower collective dose equivalent commitments. Iodine releases are expected to be much lower than for LWRs, and slightly higher than for HTGRs.

For liquid releases, the principal nuclides are Cs, Te, and $\mathrm{Sr}$ isotopes, with iodine again being an important contributor for the thyroid dose. Again, predicted releases of the most important contributors from a GCFR tend to be lower than those from LWRs or HTGRs. 
TABLE 6. Fifty-Year Collective Dose Equivalent Commitments (person-rem) for a 1-Year Release from the 1000-MWe GCFR, HTGR, and LWR

6-a. Gaseous Releases

\begin{tabular}{|c|c|c|c|}
\hline Affected Orqan & & & $\begin{array}{l}\text { alent } \\
\text { Type: }\end{array}$ \\
\hline Total Body & $2.7-3^{(a)}$ & $1.4+0$ & $1.2+1$ \\
\hline Gastrointestinal Tract & $2.7-3$ & $1.4+0$ & $1.2+7$ \\
\hline Thyroid & $6.4-3$ & $1.4+0$ & $3.2+1$ \\
\hline Bone & $8.0-4$ & $4.3-1$ & $4.3+0$ \\
\hline Lung & $2.7-3$ & $1.6+0$ & $1.2+1$ \\
\hline
\end{tabular}

(a) $2.7 \times 10^{-3}$.

6-b. Liquid Releases

\begin{tabular}{|c|c|c|c|}
\hline Affected Organ & $\begin{array}{l}\text { Collective } \\
\text { Commi tment } \\
\text { GCFR }\end{array}$ & $\begin{array}{l}\text { Dose Equive } \\
\text { by Reactor } \\
\text { HTGR }\end{array}$ & $\begin{array}{l}\text { alen } \\
\text { Typ } \\
L W\end{array}$ \\
\hline Total Body & $8.0-4$ & $4.4-1$ & \\
\hline Gastrointestinal Tract & $1.0-2$ & $2.4-2$ & \\
\hline Thyroid & $4.7-4$ & $9.1-4$ & \\
\hline Bone & $6.6-4$ & $5.8-1$ & \\
\hline ung & $6.8-5$ & $4.6-2$ & \\
\hline
\end{tabular}

TABLE 7. Fifty-Year Collective Dose Equivalent Commitments (person-rem) for a
1-Year Release of Tritium from the 1000-MWe GCFR Affected Body Collective Dose Equivalent Commitment (b)

Total Body

Gastrointestinal Tract

Thyroid

Bone

Lung
$1.9 \times 10^{-3}$

$1.9 \times 10^{-3}$

$1.9 \times 10^{-3}$

0.0

$1.9 \times 10^{-3}$

(a) Tritium is assumed to be released via airborne pathways only.

(b) Approximately $65 \%$ of tritium is assumed to be produced by ternary fission process (see text). 
The lower releases of volatile nuclides from the GCFR is attributable to the efficiency of the charcoal traps in the fuel venting and helium purification systems. The only mechanism for release of these nuclides is through sma11 amounts of contamination that result when the filter bed is changed out and disposed of as solid waste. No breakthrough is expected at the filter.

The HPS technology for the GCFR has been transferred from the HTGR essentially complete. The two reactor types have virtually the same methods for the removal of volatiles and noble gases. An examination of Table 5, however, shows that the HTGR releases far more noble gases to the environment than the GCFR is expected to. The reason for this is that fission gases produced in the GCFR are routed immediately to the HPS. Only a very small fraction diffuses or leaks to the primary coolant, maintaining a low inventory in the coolant. In the HTGR, these fission gases circulate in the primary coolant before reaching the HPS. The resulting higher inventory allows more krypton, xenon, and other fission products to leak to containment or to the secondary coolant. This naturally results in higher releases of these radionuclides to the environment. 


\section{REFERENCES}

Acharya, R. T., R. J. Campana, and S. Langer. 1980. Gas-Cooled Fast Breeder Reactor Steady-State Irradiation Testing Program. GA-A15584, General Atomic Company, San Diego, California.

Brenchley, D. L., et a1. 1977. Environmental Assessment Methodology for the Nuclear Fuel Cycle. BNWL-2219, Pacific Northwest Laboratory, Richland, Washington.

Goodin, D. T., S. Langer, and W. E. Bell. 1980. End of Life Fission Product Distributions in F-1 Experiment Fuel Rods. GA-A15916, General Atomic Company, San Diego, California.

Langer, S., G. Buzzelli, and P.W. Flynn. 1975. Postirradiation Examination of Charcoal Trap in Irradiation Capsule GB-9. GA-A13298, General Atomic Company, San Diego, California.

Ti11, J. E., E. L. Etnier, and H. R. Meyer. 1980. "Updating the Tritium Quality Factor - The Argument for Conservatism." Paper presented at the American Nuclear Society National Topical Meeting on Tritium, April 29 May 1, 1980, Dayton, Ohio.

Ti11, J. E., et a1. 1980. Tritium - An Analysis of Key Environmental and Dosimetric Questions. ORNL/TM-6990, Oak Ridge National Laboratory, Oak Ridge, Tennessee.

U.S. Department of Energy (DOE). 1980. Gas-Cooled Fast Reactor, Vol. V of "Preliminary Safety and Environmental Information Document." DOE/NE-0003/6, Washington, DC. 


\section{DISTRIBUTION}

No. of

Copies

OFFSITE

A. A. Churm

DOE Chicago Patent Group

9800 South Cass Avenue

Argonne, IL 60439

R. W. Ramsey

DOE Division of Environmental and Safety Engineering

Washington, D.C. 20545

W. E. Mott

DOE Division of Environmental and Safety Engineering

Washington, D.C. 20545

J. Counts

DOE Division of Environmental and Safety Engineering

Washington, D.C. 20545

27 DOE Technical Information Center

\section{$\underline{\text { ONSITE }}$}

DOE Richland Operations

H. E. Ransom

48

Pacific Northwest Laboratory

R. L. Aaberg

W. J. Bailey

W. J. Bair

A. Brandstetter

D. B. Cearlock

L. L. Clark

M. O. Cloninger
No. of

Copies

C. Cowan

G. W. Dawson

D. A. Dingee

W. I. Ender 1 in

R. M. Fleischman

J. C. Fox

A. J. Haverfield

C. M. Heeb

D. L. Hesse1

J. H. Jarrett

W. E. Kennedy, Jr.

H. V. Larson

R. C. Liikala

R. W. McKee

B. A. Napier

J. M. Nielsen

A. M. Nolan (10)

A. M. Platt

T. B. Powers

R. J. Serne

J. E. Tanner

B. E. Vaughn

E. C. Watson

L. D. Williams

J. K. Young

Technical Information (5)

Publishing Coordination $\mathrm{Ha} \mathrm{(2)}$ 